\title{
Effects of cladode age on biomass yield and nutritional value of intensively produced spineless cactus for ruminants
}

\author{
J.M. Pinos-Rodríguez ${ }^{1 \#}$, J.C. Velázquez ${ }^{2}$, S.S. González ${ }^{2}$, J.R. Aguirre ${ }^{1}$, J.C. García ${ }^{1}$, \\ G. Álvarez ${ }^{1}$ and Y. Jasso ${ }^{1}$ \\ ${ }^{1}$ Instituto de Investigación de Zonas Desérticas, Universidad Autónoma de San Luis Potosí, San Luis Potosí, S.L.P. \\ 78377, México \\ ${ }^{2}$ Ganadería, Colegio de Posgraduados, Montecillo, 56230, México
}

\begin{abstract}
A randomized complete block design with five replications was used to assess biomass yield, in vitro dry matter digestibility (IVDMD) and nutritional value of spineless cactus (Opuntia ficus-indica) produced under drip irrigation and fertilization. Cladodes were harvested from an established plantation at 30, 37, 45, 60,75 and $90 \mathrm{~d}$ of growth. Weight per cladode increased linearly and length increased quadratically with maturity. Biomass yield (t/ha), gross energy (GE), dry matter (DM), crude protein (CP), neutral detergent fibre and acid detergent fibre increased quadratically with maturity. Thus, the curve became asymptotic at $60 \mathrm{~d}$ of growth $(28.9 \pm 2.1 \mathrm{~cm})$. As growth progressed, concentration of CP and nitrates decreased, and that of fibre increased. In vitro solubility, potential digestibility and digestibility rate of DM decreased linearly with increased maturity of the cladodes. However, there was a quadratic effect of maturity on total digestibility of DM. Thus, the curve became asymptote at $75 \mathrm{~d}$. The optimal yield of nutrients, nutritional value and IVDMD of cladodes were recorded between 60 and $75 \mathrm{~d}$ of age when they were 29 to $31 \mathrm{~cm}$ in length.
\end{abstract}

Keywords: Biomass yield, chemical composition, digestibility, maturity, spineless cactus

${ }^{\#}$ Corresponding author. E-mail: jpinos@uaslp.mx

\section{Introduction}

Spineless cactus (Opuntia ficus-indica) plantations are a profitable investment of several arid and semi-arid areas of the world (Guevara et al., 2009). The fruit and immature cladodes of spineless cactus are used as human food (Claassens \& Wessels, 1997; Einkamerer et al., 2009), and the mature stems or cladodes can be used for feeding ruminants (De Waal et al., 2006). Nutritional quality depends partially on the species, but it decreases with ageing of the cladode (Tegegne, 2002). For years spineless cactus has been evaluated as a partial replacement for conventional feeds in ruminant diets (Abidi et al., 2009). However, research relating maturity and nutritional value of intensively produced spineless cactus is limited (PinosRodriguez et al., 2007). There is evidence (Pinos-Rodriguez et al., 2006) suggesting that maturity (expressed as years) of spineless cactus affects in vitro dry mater digestibility (IVDMD). Thus, it is hypothesized that increasing maturity (expressed as days or size) of spineless cactus cladodes under drip irrigation would decrease the nutrient content and IVDMD, hence affecting its nutritional value for ruminants. The objective of this study was to evaluate the effect of stage of maturity on biomass yield, nutrient composition and IVDMD of spineless cactus under drip irrigation and fertilization as feed for ruminants.

\section{Materials and Methods}

Spineless cactus (O. ficus-indica) cladodes were collected from a commercial plantation in central Mexico $\left(23^{\circ} 15^{\prime} 00^{\prime} \mathrm{N}, 100^{\circ} 45^{\prime} 20^{\prime}\right.$ ' $\left.\mathrm{E}\right)$. The climate is arid, with an annual average temperature of $16.8^{\circ} \mathrm{C}$, $389 \mathrm{~mm}$ annual rainfall (mostly from September to November), with a marked dry season in spring. Altitude is $1887 \mathrm{~m}$ above sea level.

Spineless cactus was cultivated in strips under drip irrigation and fertilization $(90 \mathrm{~kg} \mathrm{~N} / \mathrm{ha} / \mathrm{year})$. Cladodes were planted in plastic tunnels in strips each containing three rows $(0.50 \mathrm{~m}$ separation between rows) with $0.10 \mathrm{~m}$ inter-plant spacing. The length of each strip was $40 \mathrm{~m}$. Each strip was separated by $1.80 \mathrm{~m}$ of alley space with a density of 125000 plants/ha. Along six central strips of the plantation, six $5 \mathrm{~m}$ plots 
were delimited where six treatments were randomly assigned. Treatments were six growth stages (cladode lengths of $12 \pm 2.7,17.5 \pm 2.4,23.5 \pm 2.8,28.9 \pm 2.1,32.5 \pm 2.1$ and $38.1 \pm 2.1 \mathrm{~cm}$ ) evaluated at $30,37,45$, 60,75 and $90 \mathrm{~d}$ of age, respectively.

When the cladodes of a plot reached the respective length size, they were harvested to determine yield. A $100 \mathrm{~g}$ subsample was randomly taken from each plot of harvested cladodes and stored for further analysis. Mass, length, basal and tip thickness were measured in the laboratory for all subsampled cladodes. Thereafter all cladodes for each sample were combined, cut and dried $\left(60^{\circ} \mathrm{C}\right)$ to a constant mass $(0.1 \mathrm{~kg})$ in a forced-draft oven to determine biomass production. Dry biomass accumulation was calculated from subsample dry matter (DM) content. Subsamples were ground using a Willey mill (model 4; Arthur H. Thomas Co. Philadeplhia, PA, USA) using a $1 \mathrm{~mm}$ sieve screen, and were hand-mixed to homogenize the samples. Ash, organic matter (OM), crude protein (CP), gross energy (GE) and neutral detergent fibre (NDF) (AOAC, 1997) and acid detergent fibre (ADF) (Van Soest et al., 1991) were determined. The NDF and ADF included residual ash. Nitrate content was determined by a water extraction technique (Walinga et al., 1995).

In vitro digestibility of dry matter of the spineless cactus samples was carried out according to the procedure of Tilley \& Terry (1963). Ruminal fluid was collected from three ruminally cannulated lambs (60 kg body weight) which had free access to fresh spineless cactus (O. ficus-indica) and lucerne hay. Duplicate samples of spineless cactus were incubated for $0,6,12,24,48,72 \mathrm{~h}$. In vitro ruminal kinetics of DM was calculated using the Gompertz model according to Susmel et al. (1999) as:

$\operatorname{dig}_{(t)}=a+b * \exp [(-C) \exp (-D t)]$

where: dig is the digestibility of material $(\mathrm{g} / \mathrm{kg})$ in the tube at time $t ; a$ is the ruminally soluble DM fraction $(\mathrm{g} / \mathrm{kg})$ at $t=$ time $(\mathrm{h}) ; b$ is the insoluble, but potentially digestible fraction $(\mathrm{g} / \mathrm{kg}) ; C$ is the fractional digestible rate of $a+b$; and $D$ is a parameter to measure the digestibility.

According to a Gompertz model, the fractional rate of digestibility varies as a function of time, and the average value (i.e., a constant comparable to the exponential rate of disappearance) was derived as: $\mathrm{c}=\mathrm{D} / \mathrm{C}$. The DM remaining after each incubation time was used to fit a nonlinear regression model using the NLIN option of SAS (1999).

Data on chemical composition and IVDMD were subjected to one-way analysis of variance using a mixed model (SAS, 1999). Five analyses were used as replicates, which were included as a random effect in the model. Orthogonal polynomials were used to test effects of cladode age on nutritional composition and IVDMD. As levels (days of growth) were not equally spaced, coefficients were calculated using the IML option of SAS (1999) to test linear, quadratic, and cubic effects of age. Correlations among variables, and prediction of IVDMD from nutritional composition, were calculated by Pearson correlation and linear regression. Significant differences were accepted when $\mathrm{P} \leq 0.05$.

\section{Results}

As was to be expected, average weight per cladode increased linearly $(\mathrm{P}<0.01)$ with age (Table 1$)$. There was a quadratic $(\mathrm{P}<0.01)$ relation of the average length with age increment, which means that length of cladodes at 60,75 and 90 days was similar, but higher than at 30, 37 and $45 \mathrm{~d}$.

Production of fresh biomass ( $\mathrm{t} / \mathrm{ha}$ ) and gross energy (MJ $\times 10^{3} / \mathrm{ha}$ ) of spineless cactus were quadratically related $(\mathrm{P}<0.01)$ with age; thus, both curves were asymptotic at 60 days. Also, there were quadratic $(\mathrm{P}<0.01)$ effects of days of age on $\mathrm{DM}, \mathrm{OM}$ and $\mathrm{CP}$ concentrations. The curves for DM and OM became asymptotic at 60 days, but the curve for CP became asymptotic at 45 days. Similarly, NDF and ADF levels were quadratically related with age. The curve became asymptotic for NDF level at 60 days, and at 75 days for ADF level (Table 1).

Dry matter and ash content $/ \mathrm{kg}$ in cladodes of spineless cactus were not affected $(\mathrm{P}>0.05)$ by age (Table 1). As age of cladodes increased there was a linear decrease in CP and nitrates concentrations, but a linear increase in NDF and ADF levels $(\mathrm{P}<0.05)$. As expected the soluble fraction, potentially digestible fraction of DM and its digestibility rate also decreased linearly as age increased. The exception was the total digestibility of DM which was affected quadratically by age; thus, the curve of this variable became asymptotic at 60 days. 
Table 1 Overall biomass, composition and dry matter in vitro digestibility of spineless cactus cladodes

\begin{tabular}{|c|c|c|c|c|c|c|c|}
\hline & \multicolumn{6}{|c|}{ Age (days) ${ }^{1}$} & \multirow[b]{2}{*}{ s.e.m. } \\
\hline & 30 & 37 & 45 & 60 & 75 & 90 & \\
\hline Cladode weight, $\mathrm{g}^{\mathrm{Q}}$ & 35.1 & 69.4 & 139.1 & 234.9 & 307.5 & 363.6 & 19.0 \\
\hline Cladode length, $\mathrm{cm}^{\mathrm{L}}$ & 12.0 & 17.5 & 23.5 & 28.9 & 31.5 & 32.1 & 2.1 \\
\hline \multicolumn{8}{|l|}{ Biomass } \\
\hline As fed, $\mathrm{t} / \mathrm{ha}^{\mathrm{Q}}$ & 50.2 & 98.6 & 157.9 & 214.3 & 226.9 & 221.2 & 15.1 \\
\hline Gross energy, $\mathrm{MJ} \times 10^{3} / \mathrm{ha}^{\mathrm{Q}}$ & 38.5 & 76.1 & 116.9 & 161.1 & 179.3 & 180.5 & 15.0 \\
\hline Dry matter, $\mathrm{t} / \mathrm{ha}$ & 2.7 & 5.5 & 9.0 & 12.4 & 13.8 & 13.9 & 0.7 \\
\hline Organic matter, $\mathrm{t} / \mathrm{ha}^{\mathrm{Q}}$ & 2.2 & 4.7 & 7.6 & 10.9 & 12.4 & 12.5 & 0.6 \\
\hline Crude protein, $\mathrm{t} / \mathrm{ha} \mathrm{Q}^{\mathrm{Q}}$ & 0.48 & 0.86 & 1.38 & 1.53 & 1.44 & 1.48 & 0.21 \\
\hline Neutral detergent fibre, $\mathrm{t} / \mathrm{ha}^{\mathrm{Q}}$ & 0.77 & 1.64 & 2.70 & 3.80 & 4.31 & 4.45 & 0.31 \\
\hline Acid detergent fibre, $\mathrm{t} / \mathrm{ha}{ }^{\mathrm{Q}}$ & 0.41 & 0.90 & 1.50 & 2.40 & 2.87 & 3.02 & 0.20 \\
\hline \multicolumn{8}{|l|}{ Chemical composition } \\
\hline Dry matter, $\mathrm{g} / \mathrm{kg}$ & 53 & 56 & 57 & 58 & 61 & 63 & 7.8 \\
\hline Crude protein, $\mathrm{g} / \mathrm{kg} \mathrm{DM}^{\mathrm{L}}$ & 180 & 156 & 153 & 123 & 106 & 104 & 8.1 \\
\hline Neutral detergent fibre, $\mathrm{g} / \mathrm{kg} \mathrm{DM}^{\mathrm{L}}$ & 288 & 296 & 300 & 306 & 311 & 319 & 9.8 \\
\hline Acid detergent fibre, $\mathrm{g} / \mathrm{kg} \mathrm{DM}^{\mathrm{L}}$ & 154 & 163 & 166 & 193 & 207 & 217 & 16.3 \\
\hline Ash, g/kg DM & 193 & 203 & 211 & 213 & 216 & 228 & 29.3 \\
\hline Gross energy, $\mathrm{MJ} / \mathrm{kg} \mathrm{DM}^{\mathrm{Q}}$ & 14.3 & 13.8 & 12.9 & 12.9 & 12.9 & 12.9 & 0.15 \\
\hline Nitrates, $g / \mathrm{kg} \mathrm{DM}^{\mathrm{L}}$ & 2.4 & 2.2 & 1.7 & 1.6 & 1.6 & 1.3 & 0.02 \\
\hline \multicolumn{8}{|l|}{ Dry matter in vitro digestibility } \\
\hline Solubility $(a), \mathrm{g} / \mathrm{kg} \mathrm{DM}^{\mathrm{L}}$ & 357 & 347 & 345 & 340 & 293 & 289 & 13.3 \\
\hline Potential digestibility $(b), \mathrm{g} / \mathrm{kg} \mathrm{DM}^{\mathrm{L}}$ & 483 & 460 & 408 & 396 & 389 & 378 & 16.9 \\
\hline Total digestibility $(a+b), \mathrm{g} / \mathrm{kg} \mathrm{DM}^{\mathrm{Q}}$ & 840 & 807 & 753 & 736 & 682 & 667 & 18.4 \\
\hline Digestibility rate $(k), \mathrm{g} D M / h^{\mathrm{L}}$ & 61 & 57 & 54 & 50 & 48 & 46 & 4.3 \\
\hline
\end{tabular}

${ }^{1}$ Effect of day of growth: ${ }^{\mathrm{L}}$ Linear $(\mathrm{P}<0.05),{ }^{\mathrm{Q}}$ Quadratic $(\mathrm{P}>0.01)$. 
As expected, the comparison between nutritional composition and in vitro digestibility indicated that DM, NDF, ADF and ash were negatively correlated ( $\mathrm{P}<0.05$ to $\mathrm{P}<0.001$, respectively) with the soluble fraction, potentially digestible fraction, total digestibility of DM and digestibility rate (Table 2). Positive correlations $(\mathrm{P}<0.05$ to $\mathrm{P}<0.001)$ were observed between $\mathrm{CP}, \mathrm{GE}$, and nitrate content with potentially digestible fraction, total digestibility and digestibility rate of DM of cladodes.

Table 2 Correlation (r) between chemical composition ( $\mathrm{g} / \mathrm{kg} \mathrm{DM})$ and in vitro digestibility of dry matter $(\mathrm{g} / \mathrm{kg} \mathrm{DM})$ of spineless cactus cladodes

\begin{tabular}{lllll}
\hline & \multicolumn{3}{c}{ In vitro digestibility of dry matter ${ }^{1}$} \\
\cline { 2 - 5 } & Soluble fraction $(a)$ & $\begin{array}{l}\text { Potential } \\
\text { digestibility }(b)\end{array}$ & $\begin{array}{l}\text { Total digestibility } \\
(a+b)\end{array}$ & Digestibility rate $(k)$ \\
\hline Dry matter & $-0.94^{* *}$ & $-0.90^{*}$ & $-0.97^{* *}$ & $-0.94^{* *}$ \\
Crude protein & $0.90^{*}$ & $0.91^{*}$ & $0.96^{* *}$ & $0.99^{* * *}$ \\
Neutral detergent fibre & $-0.91^{*}$ & $-0.93^{* *}$ & $-0.97^{* * *}$ & $-0.96^{* *}$ \\
Acid detergent fibre & $-0.93^{* *}$ & $-0.88^{*}$ & $-0.93^{* *}$ & $-0.97^{* * *}$ \\
Ash & $-0.95^{*}$ & $-0.94^{* *}$ & $-0.96^{* * *}$ & $-0.92^{* *}$ \\
Gross energy & 0.62 & $0.97^{* * *}$ & $0.91^{* *}$ & $0.85^{*}$ \\
Nitrates & 0.77 & $0.99^{* * *}$ & $0.95^{* *}$ & $0.92^{* *}$
\end{tabular}

${ }^{1}$ Significance: $* \mathrm{P}<0.05,{ }^{* *} \mathrm{P}<0.01,{ }^{* * *} \mathrm{P}<0.001$.

Linear regressions indicated that $\mathrm{CP}$ and NDF alone are good predictors of IVDMD (Table 3). Prediction of IVDMD by the inclusion of ADF alone was lower as compared to CP and NDF. Prediction of IVDMD was greatly improved by inclusion of $\mathrm{CP}, \mathrm{NDF}$ and $\mathrm{ADF}$ in the equation.

Table 3 Linear regression analysis to predict in vitro total digestibility of dry matter (IVDMD, g/kg DM) from crude protein $(\mathrm{CP}, \mathrm{g} / \mathrm{kg} \mathrm{DM})$, neutral-detergent fibre (NDF, $\mathrm{g} / \mathrm{kg} \mathrm{DM}$ ) and acid-detergent fibre (ADF, $\mathrm{g} / \mathrm{kg} \mathrm{DM}$ ) of O. ficus-indica

\begin{tabular}{lll}
\hline & $\mathrm{r}^{2}$ & Significance $(\mathrm{P})$ \\
\hline $\mathrm{IVDMD}=397.13+2.49 \times \mathrm{CP}$ & 0.92 & 0.002 \\
$\mathrm{IVDMD}=2862.99-7.00 \times \mathrm{NDF}$ & 0.94 & 0.001 \\
$\mathrm{IVDMD}=1260.77-2.85 \times \mathrm{ADF}$ & 0.85 & 0.008 \\
$\mathrm{IVDMD}=2033.51+0.87 \times \mathrm{CP}-4.66 \times \mathrm{NDF}$ & 0.95 & 0.01 \\
$\mathrm{IVDMD}=-43.95+3.72 \times \mathrm{CP}+1.48 \times \mathrm{ADF}$ & 0.93 & 0.02 \\
$\mathrm{IVDMD}=1946.05+2.62 \times \mathrm{CP}-7.04 \times \mathrm{NDF}+3.11 \times \mathrm{ADF}$ & 0.98 & 0.03 \\
\hline
\end{tabular}

\section{Discussion}

Weight increased rapidly during the 90 days of evaluation, whereas length increased rapidly in the first 60 days and slowly thereafter $(61-90 \mathrm{~d})$. A similar pattern was reported for this spineless cactus by Luo \& Nobel (1993) who indicated that the surface area of new daughter cladodes started from basal cladodes, showing a low initial dry weight, a slow increase the first 10 days, then more rapidly the next 20 days, and finally a linear response with time. Our results showed that the highest annual production of biomass was 
$226 \mathrm{t} / \mathrm{ha}$ fresh and $13.9 \mathrm{t} / \mathrm{ha}$ DM. For spineless cactus (O. ficus-indica) under drip irrigation, FloresHernández et al. (2004) observed an annual production of $108 \mathrm{t} / \mathrm{ha}$ fresh biomass, which represented an annual production of $21 \mathrm{t} \mathrm{DM} / \mathrm{ha}$. A survey among large dairy farmers in Mexico indicated that the annual production of maize was $62 \mathrm{t} / \mathrm{ha}$ as fresh biomass and $20 \mathrm{t} / \mathrm{ha}$ as DM (Alpura, 2005). Under the cultivation conditions of this study, the optimum harvest age of cladodes of spineless cactus was 70 days. Therefore, under this condition 90 days of age did not have any additional benefits.

The CP level of spineless cactus increased rapidly during the first 45 days and slowly thereafter, and the curve was asymptotic at 60 days. Using the maize example $(20 \mathrm{t} \mathrm{DM} / \mathrm{ha}$ per year, $90 \mathrm{~g} \mathrm{CP} / \mathrm{kg} \mathrm{DM}$; Alpura, 2005), annual production of $\mathrm{CP}$ was $1.8 \mathrm{t}$, slightly higher than the $1.5 \mathrm{t} \mathrm{CP}$ produced by spineless cactus, which would produce a similar or a higher annual amount of biomass and nutrients than traditional forages fed to ruminants. The annual fibre production of spineless cactus $(4.4 \mathrm{t} \mathrm{NDF} / \mathrm{ha}$ at $90 \mathrm{~d})$ was lower than that from maize (20 t DM/ha $\times 450 \mathrm{~g} \mathrm{NDF} / \mathrm{kg} \mathrm{DM}=9 \mathrm{t} \mathrm{NDF} / \mathrm{ha})$. However, fibre from cactus showed a high content of pectic substances which have been associated with health benefits in animals and humans (Ben Salem \& Abidi, 2009). The highest DM content $/ \mathrm{kg}$ for spineless cactus was $63 \mathrm{~g}$ at 90 days of age. For conventional forages to be acceptable alternative forages for ruminants they must show moderate to high harvestable yield of $\mathrm{DM} / \mathrm{ha}$, moderate to high energy values and a high intake potential (Hargreaves et al., 2009). It is also important that conventional forages show an adequate DM content (greater than $300 \mathrm{~g}$ $\mathrm{DM} / \mathrm{kg}$ ) in order to be preserved as silage or hay (McDonald et al., 1991). Spineless cactus possesses most of these characteristics described above; its low DM content should not be considered a negative trait since it should not be intended to be processed as silage or hay. Furthermore, the high moisture content of spineless cactus is a desirable trait for ruminants in arid or semi-arid regions where water availability is limited. The $\mathrm{CP}$ concentration of spineless cactus ranged from 104 to $180 \mathrm{~g} / \mathrm{kg} \mathrm{DM}$ which is similar to the $190 \mathrm{~g} \mathrm{CP} / \mathrm{kg}$ DM for lucerne (NRC, 2001). Nitrate concentration in spineless cactus ranged from 1.3 to $2.4 \mathrm{~g} / \mathrm{kg} \mathrm{DM}$; values considered as harmless to ruminants (Church, 1988). Ben Salem \& Abidi (2009) indicated that N quality of cactus could be considered low and supplementation of ruminants on cactus with protein sources should be considered to improve their performances. Gross energy values of spineless cactus ranged from 12.9 to $14.2 \mathrm{MJ} / \mathrm{kg} \mathrm{DM}$ which is slightly lower than the $16.3 \mathrm{MJ} / \mathrm{kg} \mathrm{DM}$ reported for maize grain by Adeola (2003).

As expected, our results showed that nutritional composition (i.e. NDF and ADF) and in vitro digestibility of spineless cactus are functions of maturation stage and are in agreement with Repetto et al. (2003). In this regard, Batista et al. (2003) stated that IVDMD of spineless cactus could be similar or higher than that of conventional forages such as lucerne. Therefore, the kinetic variables of its IVDMD suggest that spineless cactus could be good forage to ruminants. Linear regression analysis indicated that CP alone in the model gave a high prediction of IVDMD, results which are consistent with those reported by Khazaal et al. (1995). The improvement in the prediction of IVDMD was evident when CP, NDF and ADF were included in the model.

\section{Conclusions}

Based on estimates of high DM digestibility and elevated energy and protein levels, this study provides evidence that the quality of fertilized, irrigated spineless cactus as a ruminant feedstuff is comparable to conventional forages such as lucerne and maize. Optimum DM and protein production per area were reached with a $70 \mathrm{~d}$ harvest age. Contrary to most studies, tender cladodes of spineless cactus cultivated under drip irrigation and fertilization contained high levels of CP. Further studies in ruminants are necessary to evaluate the protein quality of intensively produced spineless cactus.

\section{Acknowledgements}

This research was supported by Fundación Produce San Luis Potosí A.C. through the project "El Nopal como Forraje".

\section{References}

Abidi, S., Ben Salem, H., Martín-García, A.I. \& Molina-Alcaide, E., 2009. Ruminal fermentation of spiny (Opuntia amyclae) and spineless (Opuntia ficus indica f. inermis) cactus cladodes and diets including cactus. Anim. Feed Sci. Technol. 149, 333-340. 
Adeola, O., 2003. Energy values of feed ingredients for White Pekin ducks. Int. J. Poult. Sci. 2, 318-323.

Alpura, 2005. Summer evaluation of corn hybrids for ensiling. Department of Technical Service. Grupo Alpura, México.

AOAC, 1997. Official Methods of Analysis (16th ed.). Association of Official Analytical Chemists. Arlington, Virginia, USA.

Batista, A.M.V., Mustafa, A.F., Santos, G.R.A., De Carbol, F.F.R., Dubeux Jr, J.C.B., Lira, M.A. \& Barbosa, S.B.P., 2003. Chemical composition and ruminal dry matter and crude protein degradability of spineless cactus. J. Agron. Crop Sci. 189, 123-126.

Ben Salem, H. \& Abidi, S., 2009. Recent advances on the potential use of Opuntia spp. in livestock feeding. Acta Hort. 811, 317-326.

Church, D.C., 1988. The Ruminant, Digestive Physiology and Nutrition (2 ${ }^{\text {nd }}$ ed). Prentice-Hall, Inc. Englewood Cliffs, New Jersey, USA.

Claassens, A.S. \& Wessels, A.B., 1997. Proc. $3^{\text {rd }}$ Int. Congress on Cactus Pear and Cochenille. Eds Inglese, P. \& Brutsch, M.O., Acta Hort. 438, 83-95.

De Waal, H.O., Zeeman, D.C. \& Combrinck, W.J., 2006. Wet faeces produced by sheep fed dried spineless cactus pear cladodes in balanced diets. S. Afr. J. Anim. Sci. 36 (Suppl. 1), 10-13.

Einkamerer, O.B., De Waal, H.O., Combrinck, W.J. \& Fair, M.D., 2009. Feed utilization and growth of Dorper wethers on Opuntia-based diets. S. Afr. J. Anim. Sci. 39 (Suppl. 1), 53-57.

Flores-Hernández, A., Orona-Castillo, I., Murillo-Amador, B., García-Hernández, J.L. \& Troyo-Diéguez, E., 2004. Yield and physiological traits of prickly pear cactus 'nopal' (Opuntia spp.) cultivars under drip irrigation. Agric. Water Manag. 70, 97-107.

Guevara, J.C., Suassuna, P. \& Felker, P., 2009. Opuntia forage production systems: status and prospects for rangelands applications. Rangeland Ecol. Manag. 62, 428-434.

Hargreaves, A., Hill, J. \& Leaver, J.D., 2009. Effect of stage of growth on the chemical composition, nutritive value and ensilability of whole-crop barley. Anim. Feed Sci. Technol. 152, 50-61.

Khazaal, K.A., Dentino, M.T., Ribeiro, J.M. \& Ørskov, E.R., 1995. Prediction of apparent digestibility and voluntary intake of hays fed to sheep: comparison between using fibre components, in vitro digestibility or characteristics of gas production or nylon bag degradation. Anim. Sci. 61, 527-538.

Luo, Y. \& Nobel, P.S., 1993. Growth characteristics of newly initiated cladodes of Opuntia ficus-indica as affected by shading, drought and elevated $\mathrm{CO}_{2}$. Physiol. Plant. 87, 467-474.

McDonald, P., Henderson, A.R. \& Heron, S.J.E., 1991. The Biochemistry of Silage (2nd ed.). Chalcombe Publications. Marlow, Bucks, United Kingdom.

NRC, 2001. Nutrient Requirements of Dairy Cattle (7th rev. ed.). National Academic Press. Washington, D.C., USA.

Pinos-Rodríguez, J.M., Duque-Briones, R., Reyes-Agüero, J.A., Aguirre-Rivera, J.R., García-López, J.C. \& González-Muñoz, S., 2006. Effect of species and age on nutrient content and in vitro digestibility of Opuntia spp. J. Appl. Anim. Res. 30, 13-17.

Pinos-Rodríguez, J.M., Velásquez-Blanco, J.C., González-Muñoz, S.S., García-López, J.C., Aguirre-Rivera, J.R. \& Bárcena, R., 2007. Evaluation of cactus pear (Opuntia ficus-indica) as forage in a high concentrate total mixed ration on finishing lambs. J. Appl. Anim. Res. 32, 161-164.

Repetto, J.L., González, J., Cajarville, C., Alvir, M.R. \& Rodríguez, C.A., 2003. Relationship between ruminal degradability and chemical composition of dehydrated lucerne. Anim. Res. 52, 27-36.

SAS, 1999. SAS User's Guide. Statistics, Statistical Version 8.0 Cary, North Carolina. USA.

Susmel, P., Spanghero, M. \& Stefano, B., 1999. Interpretation of rumen degradability of concentrate feeds with a Gompertz model. Anim. Feed Sci. Technol. 79, 223-237.

Tegegne, F., 2002. Fodder potential of Opuntia ficus-indica. Acta Hort. 581, 343-346.

Tilley, L.M. \& Terry, R.A., 1963. A two-stage technique for the in vitro digestion of forage crops. J. Br. Grass. Soc. 28, 104-111.

Van Soest, P.J., Robertson, J.B. \& Lewis, B.A., 1991. Methods for dietary fibre, neutral detergent fibre, and nonstarch polysaccharides in relation to animal nutrition. J. Dairy Sci. 74, 3583-3597.

Walinga, I., Van der Lee, J.J., Haba, V.J.G., Vark, W.V. \& Novazamsky, I., 1995. Plant Analysis Manual. Kluwer Academic Publishers, The Netherlands. 